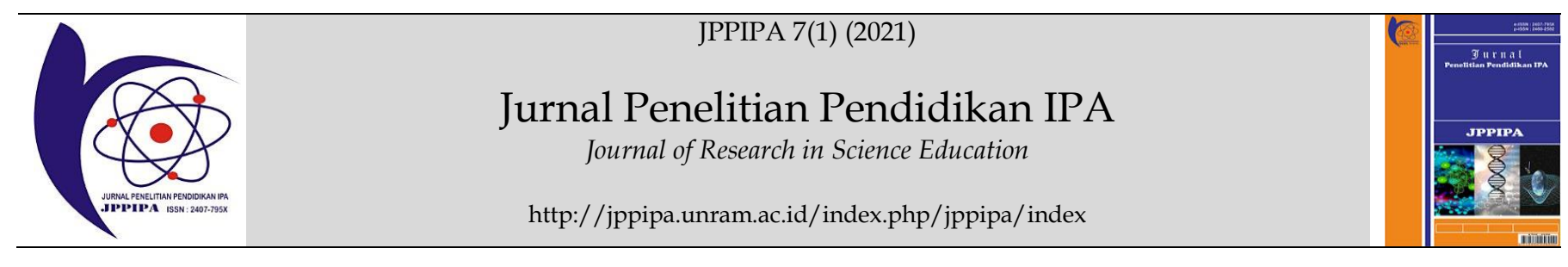

\title{
The Implementation of Performance Assessment Through Virtual Laboratory to College Students' Creative Thinking Skills
}

\author{
Ratih Permana Sari ${ }^{*}$, Mauliza², Muhammad Nazar ${ }^{3}$, Nahadi $^{4}$ \\ 1,2 Department of Chemistry Education, Universitas Samudra, Langsa, Indonesia. \\ ${ }^{3}$ Department of Chemistry Education, Universitas Syiah Kuala, Banda Aceh, Indonesia \\ ${ }^{4}$ Department of Chemistry Education, Universitas Pendidikan Indonesia, Bandung, Indonesia
}

DOI: $10.29303 /$ jppipa.v7i1.484

\section{Article Info}

Received: August 13'th, 2020

Revised: November $8^{\text {th }}, 2020$

Accepted: November 16

\begin{abstract}
Recent learning activity is tend to be implemented by guided experiment and there is an absence of further assessment. The aim of this study is to implement the performance assessment through the virtual laboratory to improve college students' creative thinking skills. This quantitative descriptive research used quasi experimental research method with one shot case study research design. The sample of this research was the college students on academic year 2018/2019 which totally amount 27 students. The performance assessment data was collected by observation instrument which applied during the preparation, implementation, and the presentation of experiment result stages of virtual laboratory learning. The result of the study showed the implementation of assessment on the presentation of experiment result stage for the whole learning materials is higher than in the preparation and implementation stage with the average score of presentation of experiment result is $88.3 \%$. The implementation of performance assessment through the virtual laboratory showed the improvement on each indicator in college students' creative thinking skills. The highest score was the evaluation indicator with the value of 0.69 . It can be concluded that the implementation of performance assessment through the virtual laboratory is able to improve college students' creative thinking skills, especially at the evaluation indicator.
\end{abstract}

Keywords: Performance Assessment; Creative Thinking Skills; Virtual Laboratory.

Citation: $\quad$ Sari, R., Mauliza, M., Nazar, M., \& Nahadi, N. (2020). The Implementation of Performance Assessment Through Virtual Laboratory to College Students' Creative Thinking Skills. Jurnal Penelitian Pendidikan IPA, 7(1), 5-10. doi:https://doi.org/10.29303/jppipa.v7i1.484

\section{Introduction}

The use of internet currently is inseparable from modern human lifestyle. The data of the survey which carried out by Indonesian Internet Network Providers Association (APJII) in 2016 showed that the college students are the largest internet users in Indonesia with the value of $89.7 \%$ and the second position is the students in lower and high school with the value of $69.8 \%$. Unfortunately their access to educational site is still low. The teachers need to act upon this circumstance by directing the college students to empower the use of internet on the educational needs (Adam, 2015).

One of the obstacles which restricted Indonesian students' ability to achieve optimum learning is the lack of learning strategies that focus on the college students' scientific skills, especially as laboratory assistants in schools. The current learning process is tended to be implemented by guided experiment by the teacher and there is no further assessment. To overcome this case, the learning strategies must run into several changes. Especially for the field of 
chemistry, almost all materials require experimental activities to support the achievement of learning objectives. One of the suitable learning approaches to be applied is virtual laboratory-based learning.

Virtual class or e-learning is a form of internet use which able to facilitate students in the learning process. The use of virtual classes is currently an interesting thing for many users, especially educators, who are almost entirely using android-based smartphones. According to Sabekti and Andriani, the use of e-learning plays a role in complementing conventional classes (face-to-face) which are implemented online, but not replacing conventional classes (Nugroho, 2012). The virtual laboratory is an interactive learning process with the help of an application in the form of a simulation of science experiments. This virtual laboratory is quite helpful in the learning process in order to improve college students' understanding of the material, and is also suitable to anticipate the unpreparedness of real laboratories (Sutrisno, 2011). Yuniarti, et al., (2012) stated that the virtual laboratory is a computer-based learning media as a solution to simulating experimental activities in a laboratory which has two components, namely simulation and animation.

Based on preliminary observations, the implementation of experiment that has been carried out is still limited to basic chemistry activities. The obstacle to carry out advanced experiment is it requires expensive laboratory equipment. The limited laboratory facilities make lecturers have difficulty to perform experiment on abstract chemical concepts. Moreover in abstract chemical concepts, there is difficulty in presenting the chemical reaction process directly through real laboratory activities, which causes mastery level of students' creative thinking skills is low.

Performance assessment is an assessment tool which suitable to be used in virtual laboratory learning, especially in terms of revealing student skills. This assessment is not only to assess learning outcomes or products, but also can be a part of learning. Performance assessment is able to measure student knowledge, reasoning, skills, products, and multiple intelligences. Chemistry is a branch of natural science that studies natural phenomena and their interactions and it is sufficiently contributive in supporting technological progress. Reflecting to the fact above, someone who studies chemistry needs to be equipped with thinking skills to be able to face these challenges. A child's brain forced to understand the information he is remember to connect it with everyday lif to produce superior humans, it requires thinking skills which can improve students' abilities in basic things (Hardiyansyah, et al., 2019). According to (Izza, et al., 2014), it is explained that thinking is a mental activity when a person face a problem and try to find a way to fix it. Several types of thinking activities are logical, analytical, systematic, critical, and creative thinking. From these various types of thinking, creative thinking can be categorized as higher order thinking. (Jamaluddin, et al., 2019) stated that order participants students can be involved and take responsibility or care about the impact of developments Science and Technology. They need to be equipped with scientific literacy skills and skills higher order thinking. Based on the explanation above, the research of implementation of performance assessment through the virtual laboratory was carried out in order to improve college students' creative thinking skills.

\section{Method}

This study has been setup as a quantitative descriptive research used the quasi experimental research method with one shot case study research design, which one group was given treatment and then observing the result. This research was conducted on May 2020 during the outbreak of Covid-19 pandemic. The location of research was initially planned to be carried out at the Basic Laboratory of Samudra University, but the pandemic of Covid-19 makes the collection of the data were carried out from the respondents home through online system. The subject of the research was collected through the purposive sampling, which composed of 27 college students' academic year 2018/2019. Data Analysis of Performance Assessment was analyzed by counting its percentage by the following formula:

$$
\mathrm{NP}=\frac{\mathrm{R}}{\mathrm{NS}} \times 100 \%
$$

where:

NP: Expected Value

$\mathrm{R}$ : Student/Group total Score

NS: maximum total score

The percentage of achievement results that $h$ ave been obtained was averaged and then matching the scores with the assessment guidelines criteria (Purwanto, 2010).

Research procedure was initially conducted by initial observation of college students' needs through direct interview. This interview was aim to reveal the essential materials to be implemented in virtual laboratory. The next stage was the compilation of research instrument which used to reveal the increase of student creative thinking skills through the performance assessment. The learning activity through the virtual laboratory was performed by the college students by preparing virtual video and presenting it through the Zoom Meeting. 
The data of performance assessment was collected through observation sheet which carried out during the preparation stage of virtual laboratory, the implementation stage of virtual laboratory, and the stage of presentation of experiment result. The instrument used was a closed-questionnaire containing a list of questions with various alternative answers based on the Likert scale. Furthermore, the data of the increase of students' creative thinking skills was measured by used an assessment rubric with modified indicators from Munandar (2009) with the highest score is five and the lowest is one. Data analysis of creative thinking skills is carried out by comparing the initial Table 1. Assessment Rubric of Creative Thinking Skills

\begin{tabular}{lll}
\hline No. & Factor & Indicator \\
\hline 1. & $\begin{array}{l}\text { Fluent thinking } \\
\text { skills }\end{array}$ & $\begin{array}{l}\text { Provide answers or ideas correcty } \\
\text { to the questions asked. }\end{array}$ \\
2. & $\begin{array}{l}\text { Flexible thinking } \\
\text { skills }\end{array}$ & $\begin{array}{l}\text { Generates a variety of answers } \\
\text { with different points of view }\end{array}$
\end{tabular}

3. Original thinking skills

Able to provide answers according to his own thoughts

4. Elaborating skills Able to specify an idea or answer to be clearer

5. Evaluating Skills

Able to conclude about the results of the experiments and final rubric scores. To measure students' creative thinking skills, the N-Gain Formula (Sundayana, 2010) was used as follow:

$$
\mathrm{N}-\text { Gain }=\left[\frac{\mathrm{N}_{\mathrm{B}-\mathrm{N}_{\mathrm{A}}}}{\mathrm{N}_{\mathrm{MAX}}-\mathrm{N}_{\mathrm{A}}}\right] \mathrm{X} 100 \%
$$

where:

$\mathrm{N}_{\mathrm{A}} \quad=$ initial score

$\mathrm{N}_{\mathrm{B}} \quad$ = final score

$\mathrm{N}_{\mathrm{MAX}}=$ ideal score

The fifth indicators were modified into assessment rubric which presented in the Table 1.

$\begin{array}{ll}\text { Rubric } & \text { Score } \\ \begin{array}{l}\text { Students answer questions correctly accompanied } \\ \text { by an explanation }\end{array} & 5 \\ \begin{array}{l}\text { Students answer with the incorrect answer } \\ \text { accompanied by an explanation }\end{array} & 3 \\ \begin{array}{l}\text { Students answered with incorrect answers and no } \\ \text { explanation }\end{array} & 1 \\ \begin{array}{l}\text { Students give varied answers with different points } \\ \text { of view with the right answer. }\end{array} & 5 \\ \begin{array}{l}\text { Students give varied answers with different points } \\ \text { of view with less precise answers. }\end{array} & 3 \\ \begin{array}{l}\text { Students give varied answers with different points } \\ \text { of view with incorrect answers. }\end{array} & 1\end{array}$

Able to provide answers according to his $\quad 5$ own thoughts

Students answer the questions in their own words and based on the results of their own thoughts, but the answer is correct Students answer questions with others words and not based on the results of their own thinking and the answer is incorrect Students answer questions in detail and answer correctly Students answer questions with no details 3 and the answer is correct Students answer questions with no details 1 and the answers is incorrect Students answer questions accurately. 5 Students answer the questions correctly but 3 from other people's point of view Students answer from other people's point of 1 view and the answer is wrong.

(Haryanti \& Saputra, 2019)

\section{Result and Discussion}

The data analysis of student needs which obtained through interview found that the learning material included into the virtual laboratory as follow:
Table. 2 Percentage of Virtual Laboratory Learning Materials

\begin{tabular}{lc}
\hline \multicolumn{1}{c}{ Learning Materials } & Percentage (\%) \\
\hline Acid-Base Titration & 90 \\
Substance Purification & 85 \\
Chemical Reactions & 80 \\
Solution Stoichiometry & 75 \\
Thermochemistry & 70 \\
\hline
\end{tabular}


The table shows that there are three learning materials that rank the highest position. Since the learning material provided in virtual laboratory is based on the results of the student needs analysis, the acid-base titration material, substance purification and chemical reactions were used as material for student presentations. The high percentage of responses to acid-base titration material is influenced by its abstract concept and complex calculations. Acid-base titration material is categorized as a difficult material for most of the students because of its abstract of concept. This is in accordance with the research of Marzuki and Astuti (2017) that the students have difficulty in understanding the concept of acid-base material which composed of writing down equations and balancing the equations for the reaction of sulfuric acid and sodium hydroxide, determining the concentration of acid which has two valences and determining the concentration of acids and bases with one valence.

Virtual laboratory is providing a fun learning atmosphere which can improve students' creative thinking skills. Moreover, virtual laboratory simplifies and make students easier to do practical work and understand chemical concepts. This is in line with research by Jagodzinski and Wolski (2014) that learning using virtual laboratories has a positive impact on improving teaching efficiency. The students also have increase in remembering information and show greater improvement in remembering material information (concepts).

Table 3. Implementation of Performance Assessment to the improvement of students' creative thinking skills

\begin{tabular}{|c|c|c|c|c|c|}
\hline \multirow{2}{*}{$\begin{array}{l}\text { Implementation of Performance } \\
\text { Assessment }\end{array}$} & \multicolumn{5}{|c|}{ N-Gain Score } \\
\hline & Fluent & Flexible & Original & Collaboration & Evaluation \\
\hline Preparation of Experiment & 0.60 & 0.62 & 0.66 & 0.62 & 0.65 \\
\hline Implementation of Experiment & 0.65 & 0.65 & 0.67 & 0.65 & 0.68 \\
\hline Presentation of Experiment Result & 0.72 & 0.70 & 0.72 & 0.73 & 0.75 \\
\hline Average & 0.65 & 0.66 & 0.68 & 0.67 & 0.69 \\
\hline
\end{tabular}

Figure 2. The graph of implementation of performance assessment to students' creative thinking skills

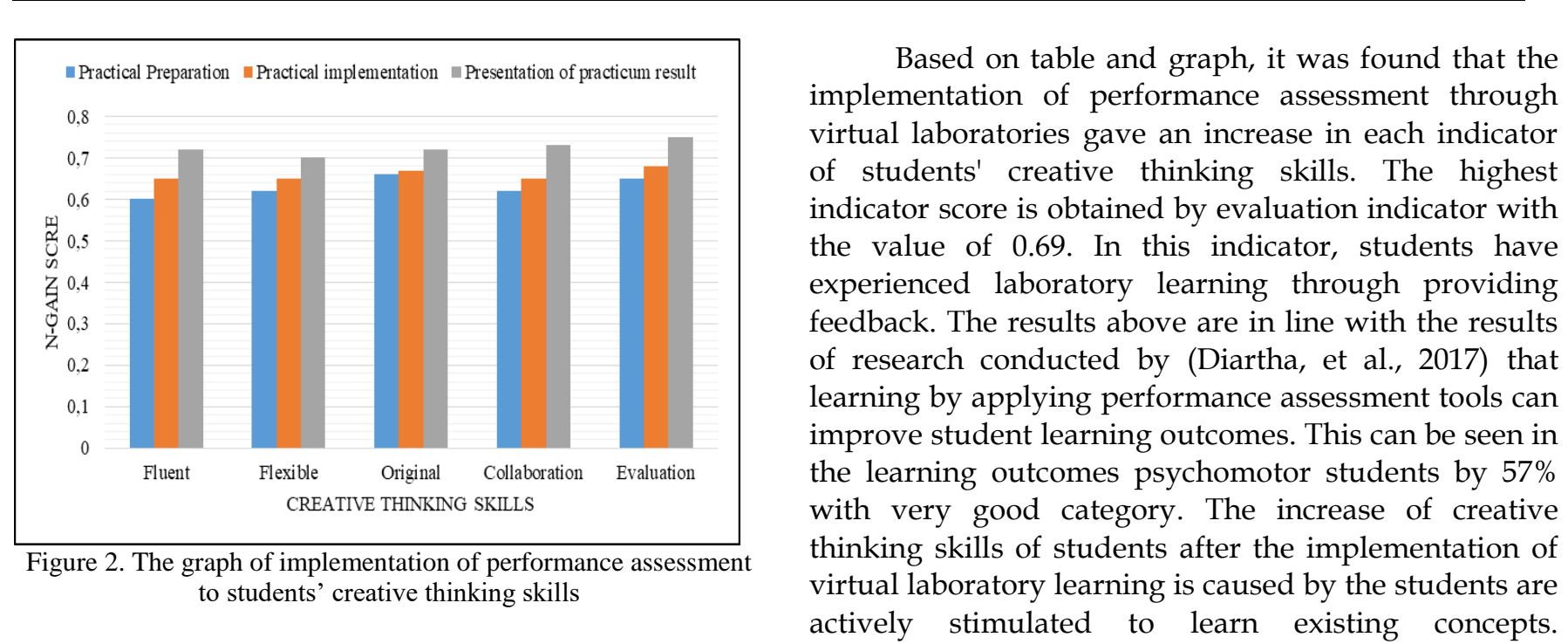

The results of the implementation of the performance assessment on each material that have been determined are obtained as follows.

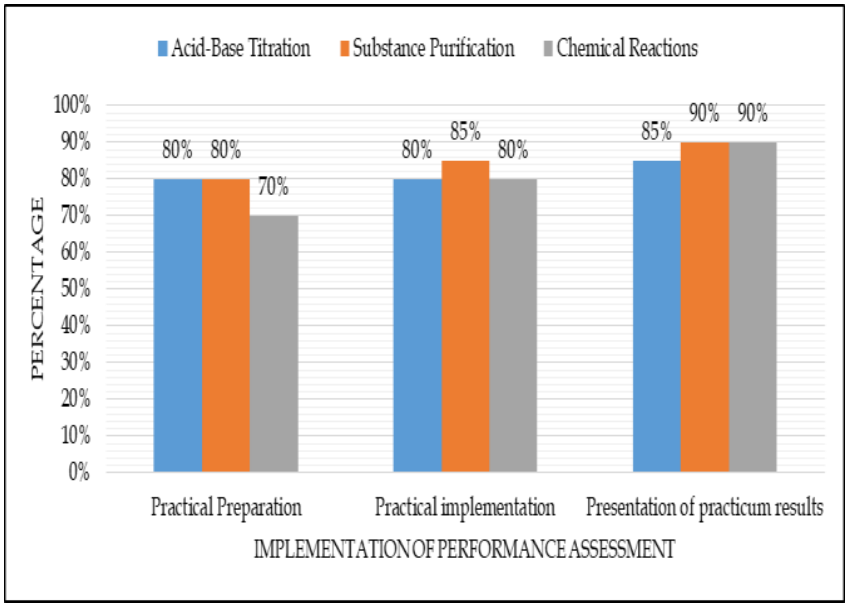

Figure 1. The graph of the implementation of performance assessment through virtual laboratory

The figure 1 reveals the implementation of the assessment in the presentation of experiment result stage for all materials is score higher than in the preparation and implementation stage with the average percentage of experiment results is $88.3 \%$.

Furthermore, the data on the implementation of performance assessment on creative thinking skills can be seen in the table 3 and figure 2 . 
Furthermore, they were given the opportunity to prepare the experiment design before the experiment starts. The results above are in line with the results of research conducted by Omidi, Sridhar, and Azizmalayeri (2012) argue that usage performance assessment in the classroom make learning more active and students are more motivated towards teaching materials.

The results above virtyal laboratory are in line with the results of research conducted by Salam (2010) that the modern physics virtual laboratory can improve the general scientific skills for prospective teachers. In addition, according to Hermanysah, et al. (2015) the use of virtual laboratory media is very efficient and effective in the science learning process so that it can improve student skills in conducting virtual experiments. Furthermore, the research findings of Suniati, et al. (2013) concluded that the effectiveness of media and multimedia in experiment is including into high category which indicated by the high increase in student' learning achievement. Sanggara \& Doyan, (2019) stated that a virtual laboratory is a media that is very suitable for the learning process in the laboratory without using real experimental tools.

Virtual laboratory learning media is one solution to the limited availability of laboratory facilities and infrastructure, especially on basic chemistry materials. Khairunnisak (2018) stated that through technologybased learning media can make students more interested in learning so that this can occur understanding concepts for them during the learning process teaching takes place. According to Hikmah, et al. (2017) the implementation of experiment simulations through computer media can help the experiment learning process for those who do not have adequate laboratory facilities, especially during the pandemic of Covid-19. Moreover, the scientific skills quality of graduated students will be accommodated through the virtual laboratory. The advantage of the implementation of virtual laboratory-based learning is it can be used to visualize simulations and simplify abstract chemical concepts into a real concept which can avoid misconceptions

\section{Conclusion}

The findings of the research figured out that the implementation of the performance assessment at the presentation of experiment results stage for all materials was higher than in preparation and implementation stage with the average percentage of experiment results was $88.3 \%$. Implementation of performance assessment through virtual laboratory provides an increase in each indicator of students' creative thinking skills. The highest indicator score is obtained by evaluation indicator with the value of 0.69 . So it can be concluded that the application of performance assessment through virtual laboratory learning can improve students' creative thinking skills, especially in evaluation indicator.

\section{Acknowledgements}

Special gratitude is expressed to the Ministry of Research, Technology and Higher Education for the assistance of Research Funds for Leading Lecturers according to Decree number 545 / UN54.6 / PG / 2020. Furthermore, thanks to LPPM team who has facilitated the research, the Chemistry Laboratory Assistant, and the lecturers of the Chemistry Education Study Program, Faculty of Education, Universitas Samudra who have contributed to the implementation of this research.

\section{References}

Adam, S. (2015). Pemanfaatan Media Pembelajaran Berbasis Teknologi Informasi Bagi Siswa Kelas X Sma Ananda Batam. Computer Based Information System Journal, 3(2). Retrieved from http://113.212.163.133/index.php/cbis/art icle/view $/ 400$

Diartha, Widan \& Muntari. (2017) Pengembangan Perangkat Penilaian Kinerja (Performance Assessment) Berbasis Kurikulum 2013 Pada Pembelajaran Kimia Kelas XI. Jurnal Penelitian Pendidikan IPA (JPPIPA), 5 (2). Retrieved form: 42-51.

http://jppipa.unram.ac.id/index.php/jppipa/ar ticle/view/91/60

Hardiyansyah, A., Doyan, A., Jufri, W. A., Susilawati, Jamaluddin. (2019). Analysis of Validation Development of Learning Media of Microscope Digital Portable Auto Design to Improve Student Creativity and Problem-Solving Ability. Jurnal Penelitian Pendidikan IPA (JPPIPA), 5 (2), 228-232. Doi: $10.29303 /$ jppipa.v5i2.273.

Haryanti, Y. D. \& Saputra, D. S. (2019). Instrumen Penilaian Berpikir Kreatif Pada Pendidikan Abad 21. Jurnal Cakrawala Pendas. 5(2), 58-64. Retrieved form: https://www.researchgate.net/publication/336 277045_instrumen_penilaian_berpikir_kreatif_pa da_pendidikan_abad_21

Hermansyah, Gunawan \& Herayati, L. (2015). Pengaruh Penggunaan Laboratorium Virtual Terhadap Penguasaan Konsep Dan Kemampuan Berpikir Kreatif Siswa Pada Materi Getaran Dan 
Gelombang. Jurnal Pendidikan Fisika dan Teknologi. 1(2), 97-102. Retrieved form: https://jurnalfkip.unram.ac.id/index.php/JPFT /article/view/242

Hikmah, N., Saridewi, N. \& Agung S. (2017). Penerapan Laboratorium Virtual untuk Meningkatkan Pemahaman Konsep Siswa. Educhemia: Jurnal Kimia dan Pendidikan. 2(2), 186-195. Retrieved form: http://jurnal.untirta.ac.id/index.php/EduCh emia/article/view/1608

Izza, L. N., Susilaningsih, E. \& Harjito. (2014). Analisis Instrumen Performance Assessment dengan Metode Generalizability Coefficient pada Penilaian Keterampilan Dasar Laboratorium. Chemistry in Education. 3(1), 30-36. Retrieved form:

https://journal.unnes.ac.id/sju/index.php/che mined/article/view/1772

Jamaluddin, Jufri, A. W., Ramdhani, A., Azizah, A. (2019). Profil Literasi Sains Dan Keterampilan Berpikir Kritis Pendidik IPA SMP. Jurnal Penelitian Pendidikan IPA (JPPIPA), 5 (1), 120-126. Retrieved

form: http://jppipa.unram.ac.id/index.php/jppipa/ar ticle/view/185/143

Jagodzinski, P \& Wolski, R. (2014). The examination of the impact on students' use of gestures while working in a virtual chemical laboratory for their cognitive abilities. Problem of Education, 61, 46-57.

Khaerunnisak. (2018). Peningkatan Pemahaman Konsep Dan Motivasi Belajar Siswa Melalui Simulasi Physic Education Technology (PhET). Jurnal Penelitian Pendidikan IPA (JPPIPA), 4(2). Retrieved form: http://jppipa.unram.ac.id/index.php/jppipa/ar ticle/view/109/82

Marzuki, H. \& Astuti, R. T. (2017). Analisis Kesulitan Pemahaman Konsep Pada Materi Titrasi Asam Basa Siswa SMA. Orbital: Jurnal Pendidikan Kimia. 1(1), 22-27. Retrieved form: http://jurnal.radenfatah.ac.id/index.php/orbita 1/article/view/1862

Munandar, U. (2009). Pengembangan Kreativitas Anak Berbakat. Jakarta: Rineka Cipta.

Nugroho, S. (2012). Profesionalisme Guru SD Negeri Se-Kecamatan

Warungasem Kabupaten Batang Suatu tinjauan aspek persepsi guru tentang kepemimpinan kepala sekolah dan motivasi berprestasi guru. Jurnal VARIDIKA, 24(2), 135146.

Retrieved form: http://journals.ums.ac.id/index.php/varidika/ article/view/710
Omidi, M. Sridhar. Y.N. Azizmalayeri, K. 2012. Effektiveness of Assessment Patterns in Chemistry Learning. Journal of Life Science. 9(3).

Purwanto. (2016). Evaluasi Hasil Belajar. Yogyakarta: Pustaka Pelajar.

Salam, H, dkk. (2010). Pembelajaran Berbasis Virtual Laboratory Untuk Meningkatkan Penguasaan Konsep pada Materi Listrik Dinamis. Proceedings of The 4th International Conference on Teacher Education; Join Conference UPI \& UPSI Bandung, Indonesia, 8-10 November 2010.

Sanggara, P. W., \& Doyan, A. (2019). The effect of Process Oriented Guided Inquiry Learning Model Based on Virtual Laboratory toward Problem Solving abilities of Physics Student. Jurnal Penelitian Pendidikan IPA, 5(1). doi: 10.29303/jppipa.v5i1.154

Sundayana, R. (2014). Statistika Penelitian Pendidikan. Bandung: Penerbit Alfabeta.

Suniati, N. M. S., Sadia, W. \& Suhandana, A. (2013). Pengaruh Implementasi Pembelajaran Kontekstual Berbantuan Multimedia Interaktif Tehadap Penurunan Miskonsepsi (Studi Kuasi Eksperimen dalam Pembelajaran Cahaya dan Alat Optik di SMP Negeri 2 Amlapura). e-Journal Program Pascasarjana Universitas Pendidikan Ganesha Program Studi Administrasi Pendidikan 4 (1). Retrieved form: http://119.252.161.254/ejournal/index.php/jurnal_ap/article/view/1019

Sutrisno. (2011). Pengantar Pembelajaran Inovatif. Jakarta: Gaung Persada Press.

Yuniarti, F., Dewi, P., Susanti, R. (2012). Pengembangan Virtual Laboratory Sebagai Media Pembelajaran Berbasis Komputer Pada Materi Pembiakan Virus. Unnes Journal Of Biology Education, 1(1), 27. Retrieved form: https://journal.unnes.ac.id/sju/index.php/ujbe /article/view/371/428 